\title{
Homocubane Chemistry: Synthesis and Structures of Mono- and Dicobaltaheteroborane Analogues of Tris- and Tetrahomocubanes
}

\author{
Kriti Pathak, ${ }^{\dagger}$ Rongala Ramalakshmi, ${ }^{\dagger, \S}$ Mohammad Zafar, ${ }^{\dagger} \S$ Sukanya Bagchi, ${ }^{\dagger}$ Thierry Roisnel, ${ }^{\ddagger}$ \\ and Sundargopal Ghosh*, ${ }^{*}$ (1)
}

\author{
${ }^{\dagger}$ Department of Chemistry, Indian Institute of Technology Madras, Chennai 600036, India \\ ${ }^{\ddagger}$ Université Rennes, CNRS, Institut des Sciences Chimiques de Rennes, UMR 6226, Rennes F-3500, France
}

\section{Supporting Information}

\begin{abstract}
Room-temperature reactions between $[\mathrm{Cp} * \mathrm{CoCl}]_{2}\left(\mathrm{Cp}^{*}=\eta^{5}-\mathrm{C}_{5} \mathrm{Me}_{5}\right)$ and large excess of $\left[\mathrm{BH}_{2} \mathrm{E}_{3}\right] \mathrm{Li}(\mathrm{E}=\mathrm{S}$ or $\mathrm{Se})$ led to the formation of homocubane derivatives, 1-7. These species are bimetallic tetrahomocubane, $\left[(\mathrm{Cp} * \mathrm{Co})_{2}(\mu-\mathrm{S})_{4}\left(\mu_{3}-\mathrm{S}\right)_{4} \mathrm{~B}_{2} \mathrm{H}_{2}\right], \mathbf{1}$; bimetallic trishomocubane isomers, $\left[(\mathrm{Cp} * \mathrm{Co})_{2}(\mu-\mathrm{S})_{3}\left(\mu_{3}-\mathrm{S}\right)_{4} \mathrm{~B}_{2} \mathrm{H}_{2}\right], 2$ and 3; monometallic trishomocubanes, $\left[\mathrm{M}(\mu-\mathrm{E})_{3}\left(\mu_{3}-\mathrm{E}\right)_{4} \mathrm{~B}_{3} \mathrm{H}_{3}\right][4: \mathrm{M}=\mathrm{Cp} * \mathrm{Co}, \mathrm{E}=\mathrm{S} ; \mathbf{5}: \mathrm{M}=\mathrm{Cp} * \mathrm{Co}, \mathrm{E}=\mathrm{Se}$ and 6: $\left.\mathrm{M}=\left\{(\mathrm{Cp} * \mathrm{Co})_{2}(\mu-\mathrm{H})\left(\mu_{3}-\mathrm{Se}\right)_{2}\right\} \mathrm{Co}, \mathrm{E}=\mathrm{Se}\right]$, and bimetallic homocubane, $\left[(\mathrm{Cp} * \mathrm{Co})_{2}(\mu\right.$-Se $\left.)\left(\mu_{3}-\mathrm{Se}\right)_{4} \mathrm{~B}_{2} \mathrm{H}_{2}\right], 7$. As per our knowledge, 1 is the first isolated and structurally characterized parent prototype of the $1,2,2^{\prime}, 4$ isomer of tetrahomocubane, while 3,4 , and 5 are the analogues of parent $D_{3}$-trishomocubane. Compounds 2 and 3 are the structural isomers in which the positions of the $\mu$-S ligands in the trishomocubane framework are altered. Compound $\mathbf{6}$ is an example of a unique vertex-fused trishomocubane derivative, in which the $D_{3}$-trishomocubane $\left[\mathrm{Co}(\mu \text {-Se })_{3}\left(\mu_{3}-\mathrm{Se}\right)_{4} \mathrm{~B}_{3} \mathrm{H}_{3}\right]$

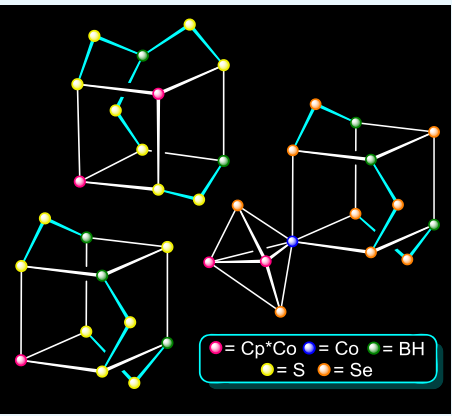
moiety is fused with an exopolyhedral trigonal bipyramid $(\mathrm{tbp})$ moiety $\left.\left[(\mathrm{Cp} * \mathrm{Co})_{2}(\mu-\mathrm{H})\left(\mu_{3}-\mathrm{Se}\right)_{2}\right\} \mathrm{Co}\right]$. Multinuclear NMR and infrared spectroscopy, mass spectrometry, and single crystal X-ray diffraction analyses were employed to characterize all the compounds in solution. Bonding in these homocubane analogues has been elucidated computationally by density functional theory methods.
\end{abstract}

\section{INTRODUCTION}

Homocubanes $^{1}$ are noncyclopropanoid homologues of cubane $^{2}\left(\mathrm{C}_{8} \mathrm{H}_{8}\right)$ derived by the introduction of one, two, three, and so forth, methylene groups into the cubane skeleton. Cubane and its derivatives were the first saturated polycyclic caged hydrocarbons to gather interest because of their potential applications in the production of high energy fuels. ${ }^{2 c, 3}$ Despite the ease of storage, handling, and proficiency under standard conditions, the synthesis of cubane is challenging as it involves multiple steps. ${ }^{2 \mathrm{~d}, 4}$ The rich chemistry of these molecules, by virtue of their inherent strain energy, has been widely exploited in the recent past. ${ }^{10,4,5}$ Despite notable growth in this field, the quest for homocubane-type species met with little success. Adams and co-workers reported homocubanes of cobalt (I-III) from the reaction of $\left[\mathrm{CpCo}(\mathrm{CO})_{2}\right]$ with chalcogen powders. ${ }^{6}$ Even though there are reports of homocubane-type molecules combining transition metals and chalcogen elements ${ }^{7}$ (I-IV, Chart 1), examples of such molecules involving boron in the cubane core, are rather limited.

Boron is a typical electron-deficient nonmetal element in group 13 with unique structural and bonding properties, and because of this, it can form diverse clusters with both the main group as well as transition metal elements. ${ }^{8-10}$ In addition, the incorporation of boron into transition metal clusters can alter the electronic properties. In line with our motivation to establish a new synthetic route for transition-metal boron compounds with interesting molecular structures, ${ }^{8-11}$ we found that $\left[\left(\mathrm{Cp}^{*} \mathrm{Mo}\right)_{2} \mathrm{~B}_{4} \mathrm{E}_{2}\right](\mathrm{E}=\mathrm{S}$, Se or Te $)$ and nido$\left[(\mathrm{Cp} * \mathrm{RuH})_{2} \mathrm{~B}_{3} \mathrm{H}_{7}\right]$ clusters are very good synthons for synthesizing cubane-type molecules. ${ }^{8}$ Recently, we have reported various trimetallic cubane-type clusters from the $\left[\mathrm{Cp}^{*} \mathrm{TaCl}_{4}\right]$ and thioborate ligand $\left[\mathrm{BH}_{2} \mathrm{~S}_{3}\right] \mathrm{Li}$ reaction. ${ }^{9 \mathrm{~b}}$ However, homocubane type of species eluded us till the dimetallapentaborane analogue, nido- $\left[(\mathrm{Cp} * \mathrm{RuH})_{2} \mathrm{~B}_{3} \mathrm{H}_{7}\right]$, generated homocubane species $\left[(\mathrm{Cp} * \mathrm{Ru})_{2} \mathrm{Mn}(\mathrm{CO})_{3}\left(\mathrm{CS}_{2} \mathrm{H}_{2}\right)\right.$ $\left.\mathrm{B}_{3} \mathrm{H}_{4}\right](\mathrm{V})$ when treated with $\left[\mathrm{Mn}_{2}(\mathrm{CO})_{10}\right] .{ }^{1 \text { la }}$ Subsequently, the isolation of electron-precise 1,3-bishomocubane derivatives $\left[(\mathrm{Cp} * \mathrm{Rh})_{2}(\mu \text {-E })_{2}\left(\mu_{3}-\mathrm{E}\right)_{4} \mathrm{~B}_{2} \mathrm{H}_{2}\right],(\mathrm{VI}: \mathrm{E}=\mathrm{S} ; \mathrm{VII}: \mathrm{E}=\mathrm{Se})$, obtained from the reaction between nido- $\left[(\mathrm{Cp} * \mathrm{Rh})_{2} \mathrm{~B}_{3} \mathrm{H}_{7}\right]$ and chalcogen powders, ${ }^{11 \mathrm{~b}}$ encouraged us to extend this approach to the cobalt system. In this article, we report the isolation and structural elucidation of dicobaltaheteroborane analogues of higher order homocubanes.

\section{RESULTS AND DISCUSSION}

Reactivity of $[\mathrm{Cp} * \mathrm{CoCl}]_{2}$ with $\left[\mathrm{BH}_{2} \mathrm{E}_{3}\right] \mathrm{Li} ;(\mathrm{E}=\mathrm{S}$ or Se). The reaction of $[\mathrm{Cp} * \mathrm{CoCl}]_{2}$ with 10 equiv. of $\left[\mathrm{BH}_{2} \mathrm{E}_{3}\right] \mathrm{Li}(\mathrm{E}=$ $\mathrm{S}$ or $\mathrm{Se})^{12}$ at room temperature, yielded a series of cobaltachalcogenaborane analogues of higher order homo-

Received: August 10, 2019

Accepted: September 11, 2019

Published: September 25, 2019 
Chart 1. Different Types of Homocubane Analogues; I-VII Previous Work, 1 This Work.

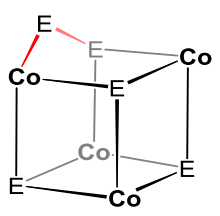

Co $=\mathrm{CpCo}$ I: $E=S, I I: E=S e$

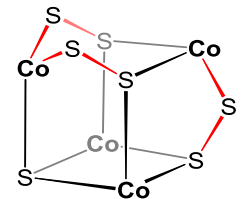

III: $\mathbf{C o}=\mathrm{CpCo}$

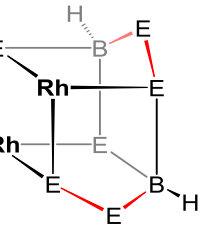

$\mathbf{R h}=C p^{*} \mathrm{Rh}$
$\mathbf{V I}: E=S$, VII: $E=S$

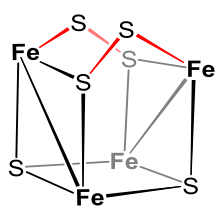

IV: $\mathbf{F e}=\mathrm{CpFe}$

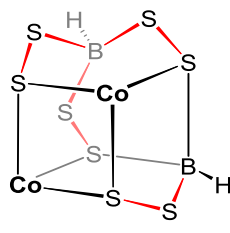

1: $\mathrm{Co}=\mathrm{Cp}{ }^{*} \mathrm{Co}$

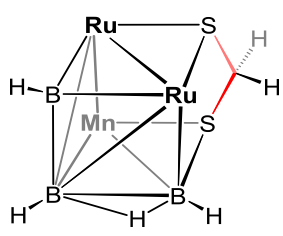

$\mathbf{v}: \mathbf{R u}=\mathrm{Cp}^{\star} \mathrm{Ru}$

$\mathrm{Mn}=\mathrm{Mn}(\mathrm{CO})_{3}$

Scheme 1. Syntheses of Homocubane Analogues 1-7

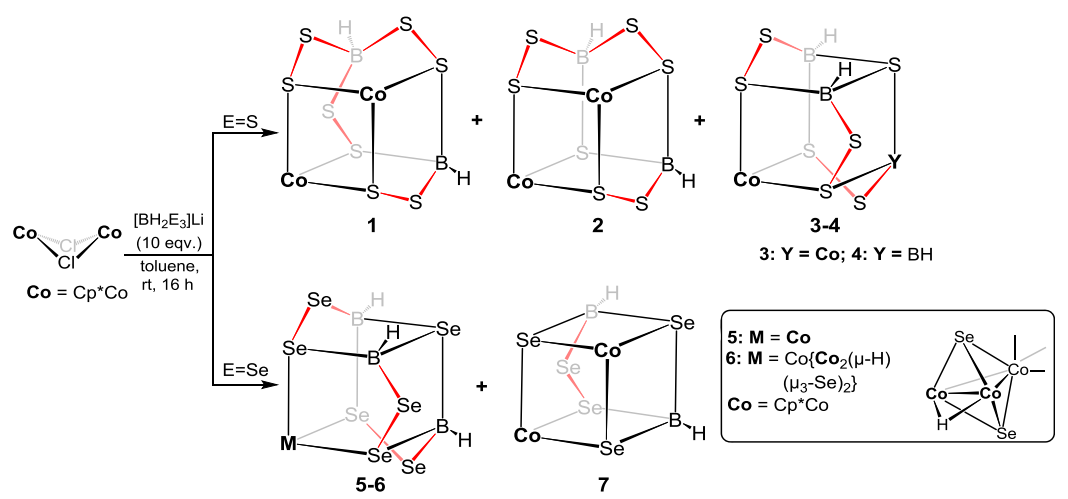

cubanes, $\mathbf{1}-7$ in $6-17 \%$ yields (Scheme 1 ). The reactions also yielded few other compounds albeit in less yields and hence could not be isolated. Reaction with $\left[\mathrm{BH}_{2} \mathrm{Te}_{3}\right] \mathrm{Li}$ led to the decomposition of the starting materials. Even though these compounds formed in a mixture, it was possible to separate them as crystalline solids through chromatographic workup by preparative thin-layer chromatography (TLC). The detailed spectral and structural characterizations of 1-7 are discussed below.

Tetrahomocubane Analogue, 1. Compound 1 was isolated along with 2 as inseparable brown solids. As we were unable to separate these two molecules by TLC, the compounds were primarily characterized by combined NMR and mass spectrometric data. ${ }^{13}$ The combined mass spectrum of 1 and $\mathbf{2}$ obtained by the electron spray ionisation (ESI) technique, exhibits molecular ion peaks at $m / z 667.9108$ and 635.9366. The room-temperature ${ }^{11} \mathrm{~B}\left\{{ }^{1} \mathrm{H}\right\}$ NMR displays four chemical shifts in the range $\delta=5.2$ to $-13.9 \mathrm{ppm}$. The ${ }^{1} \mathrm{H}$ NMR displays three chemical shifts for $\mathrm{Cp}^{*}$ protons at $\delta=$ $1.32,1.20$, and $1.18 \mathrm{ppm}$. The ${ }^{1} \mathrm{H}$ resonances at $\delta=1.32$ and $1.18 \mathrm{ppm}$ appeared with equal intensities. The ${ }^{13} \mathrm{C}\left\{{ }^{1} \mathrm{H}\right\}$ NMR also displays chemical shifts that corroborate with three $\mathrm{Cp}^{*}$ environments. The infrared (IR) spectrum shows broad bands in the $2519-2363 \mathrm{~cm}^{-1}$ region because of stretching frequencies of the terminal $\mathrm{B}-\mathrm{H}$. The core geometries of the compounds, 1 and 2, could not be interpreted unless an X-ray structure analysis for one of them was done. In an attempt to separate compounds $\mathbf{1}$ and $\mathbf{2}$ by fractional crystallization, we could manage to get few crystals of $\mathbf{1}$ from the solution that helped us determine the crystal structure of $\mathbf{1}$.

The X-ray structural analysis established the structural identity of $\mathbf{1}$. It crystallizes in an orthorhombic crystal system with the Pnma space group. The solid-state X-ray structure of 1, shown in Figure 1, presents an open-core cubane with four $\mu$-S ligands bridging four elongated $\mathrm{B}-\mathrm{S}$ edges of the cubane framework $\left[\mathrm{Co}_{2} \mathrm{~S}_{4} \mathrm{~B}_{2}\right]$. The number and the positions of these $\mu$-S bridges, in an otherwise inherently cubane structure, are the most intriguing features of $\mathbf{1}$. Based on these features, the structure may be considered as a dicobaltathiaborane analogue of the 1,2,2',4-isomer of parent tetrahomocubane $\left[\mathrm{C}_{12} \mathrm{H}_{16}\right]$ wherein three of the $\mu$-S ligands are positioned around $\mathrm{B} 1$ bridging $\mathrm{B} 1-\mathrm{S} 1, \mathrm{~B} 1-\mathrm{S} 4$, and $\mathrm{B} 1-\mathrm{S} 4$ edges of the cube while one $\mu$-S ligand is at B2, bridging the B2-S6 edge. Even though both the boron atoms in $\mathbf{1}$ are in a tetrahedral environment with three $\mathrm{S}$ and one $\mathrm{H}$, the $\mathrm{S}-\mathrm{B}-\mathrm{S}$ bond angles deviate abnormally from $109.5^{\circ}$ (maximum deviation of $21.7^{\circ}$ ). The planarity of the square face $\mathrm{Co}-\mathrm{S}-\mathrm{Co}-\mathrm{S}$ in $\mathbf{1}$ is also noticeably lost (maximum deviation is $11.9^{\circ}$ ). The average bond length for $\mathrm{B}-\mathrm{S}$ and $\mathrm{Co}-\mathrm{S}$ of 1.866 and $2.233 \AA$, respectively, is comparable with metallathiaborane clusters ${ }^{14}$ (1.875 and $2.351 \AA$ ).

Compound 1 possesses crystallographic mirror symmetry, which is defined by the B1-S2-S1-S6-S5-B2 plane. This makes the Co atoms, residing on either side of the plane, chemically equivalent. Therefore, all the $\mathrm{Cp}^{*}$ protons should correspond to a single chemical shift in the ${ }^{1} \mathrm{H}$ NMR spectrum. 


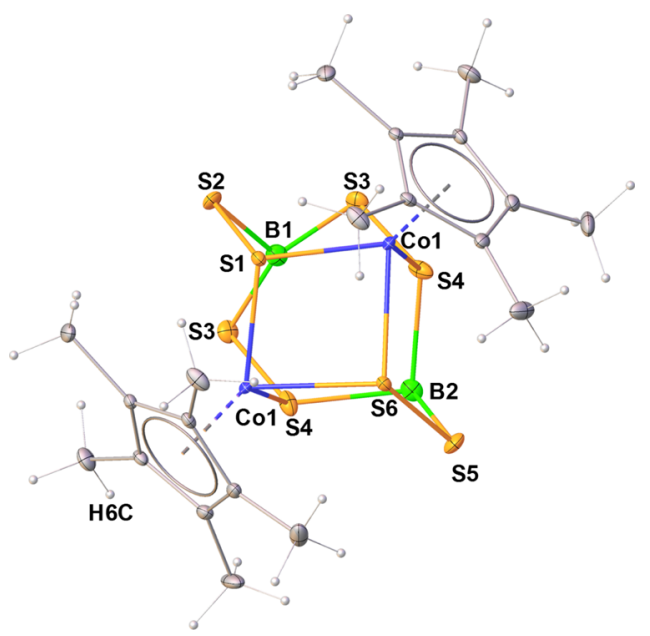

Figure 1. Molecular structure and labelling diagram of $\mathbf{1}$. Thermal ellipsoids are drawn at a $40 \%$ probability level. Selected bond lengths $[\AA]$ and angles $\left({ }^{\circ}\right)$ : Co1-S1 2.140(10), Co1-S6 2.306(10), B1-S2 1.869(12), B1-S3 1.651(7), B2-S4 2.049(12), B2-S5 1.897(16), S3-B1-S2 112.8(5), S3-B1-S3 131.2(9), S5-B2-S4 101.4(6), S4-B2-S4 97.8(8).

Interestingly, even though the mirror plane passes through two boron atoms (B1 and B2), their chemical environments are dissimilar. While $\mathrm{B} 1$ is connected to three $\mu$-S units, B2 is connected to two $\mu_{3}-\mathrm{S}$ and one $\mu$-S units. Although it was not possible to locate the terminal $\mathrm{B}-\mathrm{H}$ protons of 1 by $\mathrm{X}$-ray diffraction analysis, the ${ }^{1} \mathrm{H}\left\{{ }^{11} \mathrm{~B}\right\}$ NMR and IR spectra along with the mass spectrometric analysis confirmed their presence. Synthesis of higher order homocubanes or their derivatives is still a big challenge to synthetic chemists. The only tetrahomocubane core reported till date is observed in tetraasteran-1,4,5,8-tetracarboxylic acid, as pentacyclo$\left[6.4 \cdot 0 \cdot 0^{2,7} \cdot 0^{4,11} \cdot 0^{5,10}\right]$ dodecane, $(1,3,5,7$ isomer of tetrahomocubane; ${ }^{15 a}$ Figure 2$)$. Therefore, to the best of our knowledge, 1 is the first prototype of pentacyclo $\left[6 \cdot 3 \cdot 1 \cdot 0^{2,6} \cdot 0^{3,11} \cdot 0^{5,10}\right]$ dodecane or $1,2,2^{\prime}, 4$ isomer of tetrahomocubane (Figure 2 ).

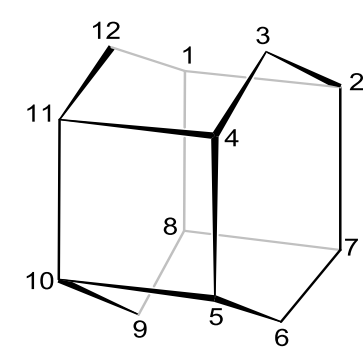

(a)

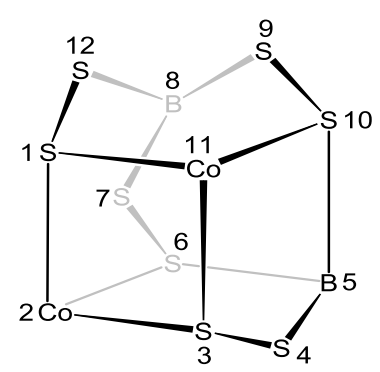

(b)
Figure 2. Schematic drawing of (a) $\mathrm{C}_{12} \mathrm{H}_{16}$, pentacyclo$\left[6.4 \cdot 0 \cdot 0^{2,7} \cdot 0^{4,11} \cdot 0^{5,10}\right]$ dodecane; ${ }^{15}(\mathrm{~b})$ the dicobaltathiaborane analogue of $\mathrm{C}_{12} \mathrm{H}_{16}, 1$, pentacyclo $\left[6 \cdot 3 \cdot 1 \cdot 0^{2,6} \cdot 0^{3,11} \cdot 0^{5,10}\right]$ dodecane.

In general, most of the cubanes and their derivatives are electron precise species following two center-two electron $(2 \mathrm{c}-2 \mathrm{e})$ bonding, wherein the metals obey the 18-electron rule while the main group elements follow the octet rule. ${ }^{16}$ Compound 1, a dimetalla analogue of tetrahomocubane $\left(\mathrm{C}_{12} \mathrm{H}_{16}\right)\left[\mathrm{cve}=64 ;\left\{8(\mathrm{CH}) \times 5+4\left(\mathrm{CH}_{2}\right) \times 6\right\}\right]$, possesses 84 cve count $\left[2\left(\mathrm{Cp}^{*} \mathrm{Co}\right) \times 14+8(\mathrm{~S} / \mathrm{Se}) \times 6+2(\mathrm{BH}) \times 4\right]$ thereby satisfying the $2 c-2 e$ formalism. A similar situation has also been observed for other bishomocubane derivatives $\left[(\mathrm{Cp} * \mathrm{Rh})_{2}(\mu-\mathrm{E})_{2}\left(\mu_{3}-\mathrm{E}\right)_{4} \mathrm{~B}_{2} \mathrm{H}_{2}\right] \quad(\mathrm{E}=\mathrm{S}$ or $\mathrm{Se})$ and $\left[(\mathrm{Cp} * \mathrm{Ru})_{2}(\mu-\mathrm{E})_{2}\left(\mu_{3}-\mathrm{E}\right)_{4} \mathrm{~B}_{2} \mathrm{H}_{2}\right](\mathrm{E}=\mathrm{S}$ or $\mathrm{Se}){ }^{11 \mathrm{~b}, 17}$

Bimetallic Analogues of Trishomocubanes, 2 and 3. Compound 3 was isolated in a moderate yield, as a brown solid. The mass spectrum of 3 displayed a molecular ion peak at $m / z 635.9366$ which suggested the molecular formula $\mathrm{C}_{20} \mathrm{H}_{32} \mathrm{~B}_{2} \mathrm{~S}_{7} \mathrm{Co}_{2}$. The ${ }^{11} \mathrm{~B}\left\{{ }^{1} \mathrm{H}\right\}$ NMR of 3 , at room temperature, showed two chemical shifts at $\delta=7.1$ and $5.2 \mathrm{ppm}$. The ${ }^{1} \mathrm{H}$ NMR displayed two signals at $\delta=1.36$, and $1.19 \mathrm{ppm}$ for the $\mathrm{Cp}^{*}$ protons signifying the possibility of two chemically distinct boron and metal environments. Crystals suitable for Xray diffraction were obtained by cooling a concentrated hexane $/ \mathrm{CH}_{2} \mathrm{Cl}_{2}(80: 20)$ solution at $-10{ }^{\circ} \mathrm{C}$.

The X-ray diffraction analysis of 3 revealed a trishomocubane core, which is crystallized in an orthorhombic crystal system and Pnma space group. As represented in Figure 3, two structural residues are present in the unit cell of the solid-state crystal structure (additional details of the disorder are discussed under the X-ray structure details in the Supporting Information) crystal structures were constructed by segregating the highly entangled molecules into two meaningful core geometries and were found to exist as two interpenetrating disordered molecules related closely by a mirror plane. ${ }^{18}$ In addition to this, both the residues corresponded to identical structural parameters thereby establishing themselves as mirror equivalents or enantiomers. Hence, the molecules cannot be distinguished by multinuclear NMR spectroscopy or by mass spectrometry as they would correspond to identical chemical shifts in NMR spectroscopy and would give similar isotopic distribution pattern in mass spectrometry; ${ }^{18}$ all the spectroscopic data for 3 validate this fact.

The molecular structure of the mirror equivalent isomers of 3 is comparable to that of $\mathbf{1}$ and other cubane cores ${ }^{8,11 \mathrm{~b}}$ with three $\mu_{2}$-S ligands bridging two elongated $\mathrm{B}-\mathrm{S}$ edges and one $\mathrm{Co}-\mathrm{S}$ edge of the $\left[\mathrm{Co}_{2} \mathrm{~S}_{4} \mathrm{~B}_{2}\right]$ core. The tetrahedral environment of two $\mathrm{B}$ atoms defined by two $\mu_{3}$-S, one $\mu$-S, and one $\mathrm{H}$ atom each, is also reflected in the $\mathrm{S}-\mathrm{B}-\mathrm{S}$ bond angles which closely match with $109.5^{\circ}$ (maximum deviation $7.8^{\circ}$ in case of S6-B2-S7). The presence of the $\mu$-S bridge, viz. the Co1S1-S7 link, distorts the planarity of the Co-S-Co-S square face (maximum deviation $24.5^{\circ}$ ). Even though the average B$\mathrm{S}$ bond length in 3 is slightly longer (1.906 $\AA$ ) as compared to other metallathiaborane clusters, ${ }^{16}$ the $\mathrm{B} 1-\mathrm{S} 4$ bond length is fairly shorter $(1.797 \AA)$. The average Co-S bond length of $2.246 \AA$ is shorter relative to some of the reported metallathiaborane clusters. ${ }^{14}$

As discussed earlier, compound $\mathbf{2}$ was isolated along with $\mathbf{1}$ as an inseparable mixture. One of the molecular ion peaks in the combined mass spectrum of $\mathbf{1}$ and 2, which appeared at $\mathrm{m} /$ $z$ 635.9366, is identical with that of 3 . Thus, based on the mass spectrometric data together with the combined spectroscopic data, the composition of $\mathbf{2}$ may be considered as $\mathrm{C}_{20} \mathrm{H}_{32} \mathrm{~B}_{2} \mathrm{~S}_{7} \mathrm{Co}_{2}$. Therefore, we assume that compound 2 may be another isomer of dimetalla trishomocubane species. Although we were able to get the X-ray quality crystals for $\mathbf{1}$, unfortunately we failed to get the crystals for 2 . However, the solution of 3 in $\mathrm{CH}_{2} \mathrm{Cl}_{2}$ on keeping at room temperature for several days converted to 2 . The spectroscopic and mass spectrometric data enabled us to conclude that $\mathbf{2}$ and $\mathbf{3}$ are interconverting isomers (Scheme 2).

Fortunately, compounds $\mathbf{2}$ and $\mathbf{3}$ can be separated using toluene as an eluent. This enabled us to get the spectroscopic 


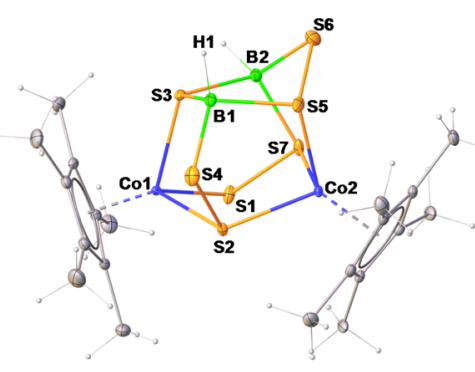

(a)

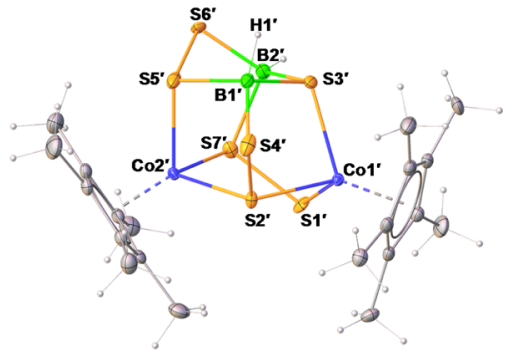

(b)

Figure 3. Molecular structure and labelling diagrams of 3(a and b). Thermal ellipsoids are drawn at $40 \%$ probability level. Selected bond lengths $[\AA]$ and angles $\left(^{\circ}\right)$ : Co1-S1 2.257(6), Co1-S2 2.230(2), Co2-S2 2.253(7), Co2-S7 2.222(17), B1-S4 1.797(16), B1-S5 1.967(12), B2-S6 1.856(14), B2-S7 1.909(12), S4-B1-S3 111.2(6), S4-B1-S5 104.8(7), S6-B2-S7 101.7(6), S7-B2-S3 109.7(6).

Scheme 2. Conversion of 3 to 2 at Room Temperature

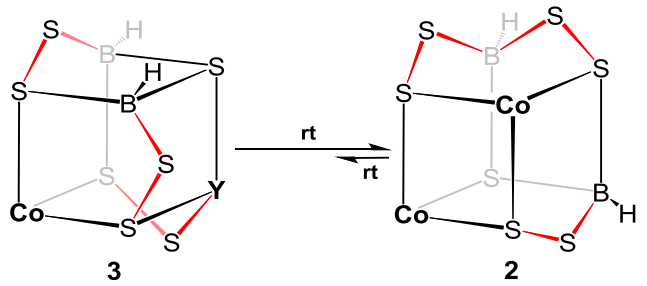

data of pure 2 and helped us assign all the combined spectroscopic data for $\mathbf{1}$ and $\mathbf{2}$. Two resonances are observed at $\delta=5.2$ and $3.6 \mathrm{ppm}$ in the ${ }^{11} \mathrm{~B}\left\{{ }^{1} \mathrm{H}\right\}$ NMR of 2 . Hence, the signals at $\delta=-4.6$ and $-13.9 \mathrm{ppm}$ in the combined ${ }^{11} \mathrm{~B}\left\{{ }^{1} \mathrm{H}\right\}$ NMR may be assigned for 1 . Similarly, the ${ }^{1} \mathrm{H}$ NMR spectrum of 2 shows two resonances corresponding to $\mathrm{Cp}^{*}$ protons at $\delta$ $=1.32$ and $1.18 \mathrm{ppm}$ therefore, ${ }^{1} \mathrm{H}$ chemical shift at $\delta=1.20$ ppm in the combined ${ }^{1} \mathrm{H}$ NMR spectrum has been assigned to $\mathrm{Cp} *$ protons of $\mathbf{1}$. Further, the ${ }^{1} \mathrm{H}$ chemical shift values of 2 also suggest the presence of two different metal environments.

Unfortunately, in spite of several attempts, we were unable to grow crystals of $\mathbf{2}$ for the X-ray diffraction analysis. However, from the spectroscopic data in combination with the mass spectrometric data of $\mathbf{2}$, it is rational to assume that compounds $\mathbf{2}$ and 3 are geometrical isomers. The structure of 2 which is shown in Schemes 1 and 2 and Figure 4, is one of the possible isomers only.

Monometallic Trishomocubane Analogues, 4-6. The reactions of $\left[\mathrm{Cp}^{*} \mathrm{CoCl}\right]_{2}$ and $\left[\mathrm{BH}_{2} \mathrm{E}_{3}\right] \mathrm{Li}(\mathrm{E}=\mathrm{S}$ or $\mathrm{Se})$ also yielded compounds 4 and 5 as orange solids. Multinuclear

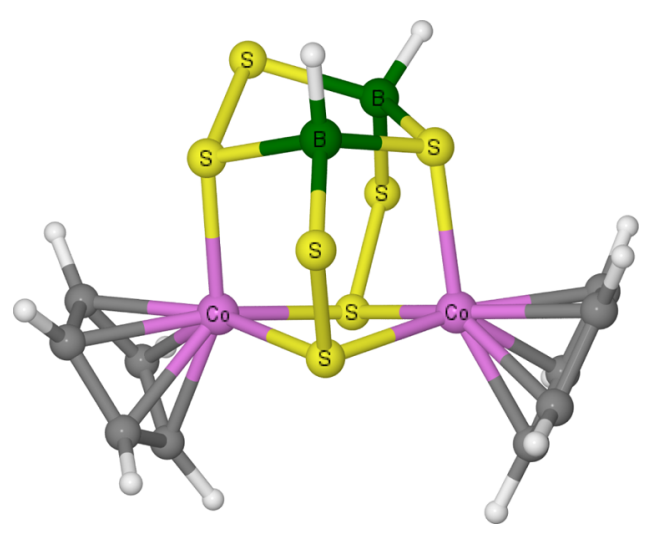

Figure 4. Probable molecular structure of 2 obtained from density functional theory (DFT) optimization.
NMR and IR spectroscopy were used to characterize both the compounds. The mass spectrometric data for 5 shows a molecular ion peak at $m / z 783.6853$ suggesting the composition of $\mathbf{5}$ as $\mathrm{C}_{10} \mathrm{H}_{19} \mathrm{~B}_{3} \mathrm{Se}_{7} \mathrm{Co}$. The ${ }^{11} \mathrm{~B}\left\{{ }^{1} \mathrm{H}\right\}$ NMR spectra of $\mathbf{4}$ and $\mathbf{5}$ are very similar showing a single resonance at $\delta=6.3$ and $0.2 \mathrm{ppm}$, respectively, suggesting symmetry in the molecules. Their ${ }^{1} \mathrm{H}$ NMR spectra displayed the signals for a single $\mathrm{Cp}^{*}$ at $\delta=1.51$ and $1.57 \mathrm{ppm}$, respectively. In addition, the ${ }^{1} \mathrm{H}$ NMR spectra of 4 and 5 showed chemical shifts in the region of $\delta=3.69-5.05 \mathrm{ppm}$ for the terminal B$\mathrm{H}$ protons. The ${ }^{13} \mathrm{C}\left\{{ }^{1} \mathrm{H}\right\}$ NMR spectra also indicate the occurrence of one $\mathrm{Cp}^{*}$ in agreement with the molecules being symmetrical. The IR spectra of 4 and 5 showed peaks at 2473 and $2462 \mathrm{~cm}^{-1}$ due to stretching frequency of the terminal B$\mathrm{H}$ bond.

Therefore, based on all the spectroscopic data of compounds 4 and 5, we assume that both of them have similar geometry. The framework geometry of one of the analogous compounds (4) was established by single crystal X-ray diffraction analysis. As shown in Figure 5a, the structure of $\mathbf{4}$ can be regarded as a trishomocubane core, in which $\left\{\mathrm{CoS}_{4} \mathrm{~B}_{3}\right\}$ defines the cubane core with three $\mu_{2}$-S ligands bridging three elongated $\mathrm{B}-\mathrm{S}$ edges of the $\mathrm{CoS}_{4} \mathrm{~B}_{3}$ framework. The core geometry of 4 is closely related to that of 3 ; the $\mathrm{Cp}^{*} \mathrm{Co}$ fragment in 3 is substituted by a $\mathrm{BH}$ unit in 4 . The X-ray crystallographic data establish that 3 and 4 are probably the first metallachalcogenaborane analogues of pentacyclo $\left[6 \cdot 3 \cdot 0 \cdot 0^{2,6} \cdot 0^{3,10} \cdot 0^{5,9}\right]$ undecane known as $D_{3}$-trishomocubane ${ }^{19}$ The $D_{3}$-trishomocubane is the smallest stable rigid organic molecule belonging to the chiral point group $D_{3}{ }^{19 \mathrm{~b}-\mathrm{d}}$ All the boron atoms are in a symmetrical tetrahedral environment provided by three $S$ and one $\mathrm{H}$ atom. The average bond length of $1.899 \AA$ is somewhat higher as compared to that of other metallathiaborane clusters. ${ }^{14}$

The reaction between $[\mathrm{Cp} * \mathrm{CoCl}]_{2}$ and $\left[\mathrm{BH}_{2} \mathrm{Se}_{3}\right] \mathrm{Li}$, in addition to yielding 5 , also yielded a brown compound 6 (Scheme 1). The constituents of 6 were confirmed by means of multinuclear NMR spectroscopy, mass spectrometry, and single crystal X-ray diffraction analysis. The mass spectrum of 6 shows a molecular ion peak at $m / z 1194.3456$ which suggests a molecular formula $\mathrm{C}_{20} \mathrm{H}_{34} \mathrm{~B}_{3} \mathrm{Se}_{9} \mathrm{Co}_{3}$. The ${ }^{11} \mathrm{~B}\left\{{ }^{1} \mathrm{H}\right\}$ NMR spectrum, at room temperature, exhibits a single resonance at $\delta=-44.6 \mathrm{ppm}$ suggesting a symmetry in the molecule. This was further supported by the presence of a single resonance in the ${ }^{1} \mathrm{H}$ NMR spectrum corresponding to $\mathrm{Cp}^{*}$ protons. Consistent with the ${ }^{11} \mathrm{~B}\left\{{ }^{1} \mathrm{H}\right\}$ and ${ }^{1} \mathrm{H}$ NMR spectra, the ${ }^{13} \mathrm{C}\left\{{ }^{1} \mathrm{H}\right\}$ NMR spectrum also supports the presence of symmetry. Moreover, the ${ }^{1} \mathrm{H}$ NMR spectrum 


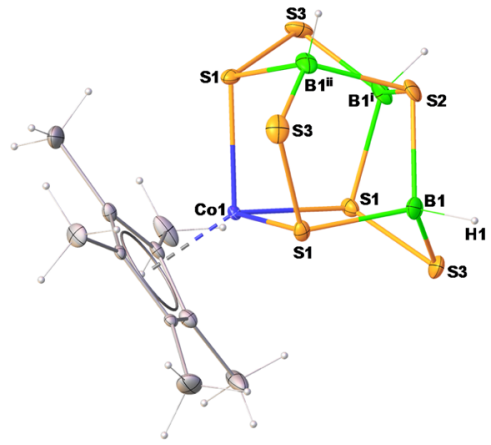

(a)

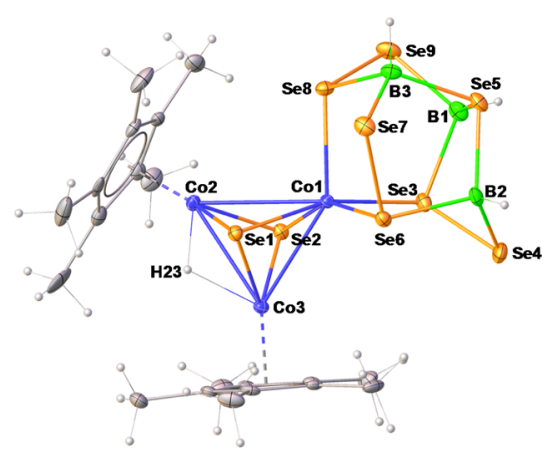

(b)

Figure 5. Molecular structures and labelling diagrams of 4 (a) and 6 (b). Thermal ellipsoids are drawn at a $40 \%$ probability level. In 4 , B $1^{\mathrm{i}}$ and $\mathrm{B} 1^{\mathrm{ii}}$ atoms are symmetry generated $(\mathrm{i}=-y+1, x-y$, $\mathrm{z} ; \mathrm{ii}=-x+y+1,-x+y+1,-x+1, z)$. Selected bond lengths $[\AA]$ and angles $\left({ }^{\circ}\right)$; 4: Co1-S1 2.246(3), B1-S1 1.979(10), B1-S2 1.968(10), B1-S3 1.750(13), S2-B1-S1 102.8(4), S1-Co1-S1 92.83(12); 6: Co1-Co2 2.942(13), Co1Co3 2.65(13), Co1-Se2 2.316(12), Co2-Se2 2.245(12), Co3-Se2 2.258(11), Co1-Se3 2.412(11), B1-Se9 2.013(11), B2-Se5 2.071(10), B3Se5 2.076(10), B3-Se7 2.026(9), Se3-B1-Se9 106.8(5).

shows an upfield peak at $\delta=-3.60 \mathrm{ppm}$. The IR spectrum features a band at $2437 \mathrm{~cm}^{-1}$ because of $\mathrm{B}-\mathrm{H}$ stretching frequencies. Although the spectroscopic data of 6 resemble that of $\mathbf{5}$ to some extent, the mass spectrometric data implies otherwise. The core structure could be comprehended only after an X-ray structure analysis was carried out with a brown rod-shaped crystal of 6 .

The X-ray structure of 6, shown in Figure 5b, can be considered as a vertex-fused cluster in which a trishomocubane moiety $\left[\mathrm{Co}(\mu \text {-Se })_{3}\left(\mu_{3}-\mathrm{Se}\right)_{4} \mathrm{~B}_{3} \mathrm{H}_{3}\right]$ and a trigonal bipyramid (tbp) cluster $\left[\left\{(\mathrm{Cp} * \mathrm{Co})_{2}(\mu-\mathrm{H})\left(\mu_{3}-\mathrm{Se}\right)_{2}\right\} \mathrm{Co}\right]$ are fused by a cobalt atom (Co1). The core geometry of $\mathbf{6}$ is similar to $\mathbf{4}$ or $\mathbf{5}$, in which the $\mathrm{Cp} * \mathrm{Co}$ fragment is replaced by the $\left[\left\{(\mathrm{Cp} * \mathrm{Co})_{2}(\mu-\mathrm{H})\left(\mu_{3}-\mathrm{Se}\right)_{2}\right\} \mathrm{Co}\right]$ moiety. The boron atoms in $\mathbf{6}$ are in a symmetrical tetrahedral environment similar to that in 4 and 5 . The $\mathrm{Se}-\mathrm{B}-\mathrm{Se}$ bond angles deviate slightly from $109.5^{\circ}$ (maximum deviation $\sim 6.8^{\circ}$ ), whereas the basal plane deviates distinctly from planarity (maximum deviation $11.9^{\circ}$ ). The average $\mathrm{B}-\mathrm{Se}$ bond length in $6(2.043 \AA)$ is notably longer as compared to that in $\left[\left(\mathrm{Cp}^{*} \mathrm{Mo}\right)_{2} \mathrm{~B}_{4} \mathrm{Se}_{2} \mathrm{H}_{4}\right](1.923$ A). ${ }^{20}$

All the spectroscopic data of 6 agreeably corroborate with its $\mathrm{X}$-ray structure. The ${ }^{1} \mathrm{H}$ chemical shift at $\delta=-3.60 \mathrm{ppm}$ is designated to the $\mathrm{Co}-\mathrm{H}-\mathrm{Co}$ proton. Typically, the ${ }^{1} \mathrm{H}$ chemical shift for the $\mathrm{Co}-\mathrm{H}-\mathrm{Co}$ proton appears in the upfield region; ${ }^{21}$ however, the HSQC experiment does not support the existence of any $\mathrm{Co}-\mathrm{H}-\mathrm{B}$ or $\mathrm{B}-\mathrm{H}-\mathrm{B}$ protons. In addition, on lowering the temperature, the ${ }^{1} \mathrm{H}$ chemical shift at $\delta=-3.60 \mathrm{ppm}$ is shifted to the up-field region.

Further, the computed ${ }^{1} \mathrm{H}$ chemical shift for the corresponding $\mathrm{Co}-\mathrm{H}-\mathrm{Co}$ proton closely matches with the experimental value (Table S4).

The electron counting rules ${ }^{22}$ by Wade, Mingos, Jemmis, in addition to connecting borane, metallaborane, metallaheteroborane, or metallacarborane clusters in a simple manner, also provided a perception for the assessment of the electronic requirements of varied cage and ring structures. Thus, the cluster valence electron (cve) counts of the trishomocubane analogues 2-6 were carried out, which were found to be in good agreement with the hydrocarbon homologue $\mathrm{C}_{11} \mathrm{H}_{14}$. For illustration, the cve for $\mathrm{C}_{11} \mathrm{H}_{14}: 8(\mathrm{CH}) \times 5+3\left(\mathrm{CH}_{2}\right) \times 6=$ 58; for 2 and 3: $2(\mathrm{Cp} * \mathrm{Co}) \times 14+7(\mathrm{~S}) \times 6+2(\mathrm{BH}) \times 4=$ 78; for 4 and 5: $1\left(\mathrm{Cp}^{*} \mathrm{Co}\right) \times 14+7(\mathrm{~S} / \mathrm{Se}) \times 6+3(\mathrm{BH}) \times 4$ $=68$. For 6 , the total valence electron count around Col can be calculated as 14 [9 (from Co1) $+1($ from Co $1-\mathrm{Co} 2)+1$ (from $\mathrm{Co} 1-\mathrm{Co} 3)+3[2$ (from $\mathrm{Se} 1 / \mathrm{Se} 2-\mathrm{Co} 3)+1$ (from $\mathrm{Se} 1 / \mathrm{Se} 2-\mathrm{Co} 3)]$, which is equivalent to that of $\mathrm{Cp}^{*} \mathrm{Co}[9$ (from $\mathrm{Co})+5$ (from $\left.\left.\mathrm{Cp}^{*}\right)\right]$. Therefore, based on the electron contribution to $\mathrm{Co} 1$, the exo- $\left\{\left(\mathrm{Cp}^{*} \mathrm{Co}\right)_{2}(\mu-\mathrm{H})\left(\mu_{3}-\mathrm{Se}\right)_{2}\right\}$ fragment can be compared with the $\mathrm{Cp} *$ ligand which makes 6 an electron precise trishomocubane analogue.

In addition to the formation of compounds 5 and $\mathbf{6}$, the reaction of $[\mathrm{Cp} * \mathrm{CoCl}]_{2}$ and $\left[\mathrm{BH}_{2} \mathrm{Se}_{3}\right] \mathrm{Li}$ at room temperature also allowed us to isolate compound 7 as a grey solid. The mass spectrum featured a molecular ion peak at $m / z 807.7211$. The ${ }^{11} \mathrm{~B}\left\{{ }^{1} \mathrm{H}\right\}$ NMR spectrum for 7 features two sharp signals with equal intensities at $\delta=-5.6$ and $-12.9 \mathrm{ppm}$. Although the ${ }^{1} \mathrm{H}$ NMR spectrum displayed a peak at $\delta=1.58 \mathrm{ppm}$ because of $\mathrm{Cp}^{*}$ protons, the ${ }^{13} \mathrm{C}\left\{{ }^{1} \mathrm{H}\right\}$ NMR spectrum indicates that two different metal environments are present in the compound. The occurrence of a single chemical shift in the ${ }^{1} \mathrm{H}$ NMR at $\delta=1.58 \mathrm{ppm}$ for two equivalents of $\mathrm{Cp}^{*}$ may be owed to the accidental overlapping of two peaks. The IR spectrum showed a broad band in the $2453 \mathrm{~cm}^{-1}$ region for the terminal $\mathrm{B}-\mathrm{H}$ units. The ${ }^{1} \mathrm{H}\left\{{ }^{11} \mathrm{~B}\right\}$ NMR experiment additionally confirmed the existence of the terminal $\mathrm{B}-\mathrm{H}$ units.

An X-ray diffraction study was done for ascertaining the molecular structure of 7 . Compound 7 shows a single $\mu_{2}$-Se ligand bridging the $\mathrm{B} 1-\mathrm{Se} 4$ edge of the cube (Figure 6). The average $\mathrm{B}-\mathrm{Se}$ bond length in $7(2.111 \AA)$ is longer as compared to that of $\left[(\mathrm{Cp} * \mathrm{Mo})_{2} \mathrm{~B}_{4} \mathrm{Se}_{2} \mathrm{H}_{4}\right]^{20}(1.923 \AA)$ and $\left[(\mathrm{Cp} * \mathrm{Ru})_{2}\left(\mu_{3}-\mathrm{Se}\right)\left(\mu_{4}-\mathrm{Se}\right) \mathrm{B}_{2} \mathrm{H}_{5}\right]^{11 \mathrm{~b}}(2.014 \AA)$.

Compound 7 possesses the expected cve count of 66 [2 $(\mathrm{Cp} * \mathrm{Co}) \times 14+5(\mathrm{Se}) \times 6+2(\mathrm{BH}) \times 4]$, thereby agreeing with the electron precise hydrocarbon homologue $\mathrm{C}_{9} \mathrm{H}_{10}$ [cve count $\left.46 ; 8(\mathrm{CH}) \times 5+1\left(\mathrm{CH}_{2}\right) \times 6\right]$ and obeying the electron counting rule.

Electronic Structure Calculations. The DFT calculations were done to understand the electronic structures of the homocubane derivatives 1-7 in a gas phase, with GGA BP86 as a functional and def2-TZVP basis set included Grimme's D3 dispersion corrections. The optimized geometrical parameters of 1-7 were found to almost agree with the crystallographic data obtained from X-ray structure analyses (Table S1). The computed and experimental values for ${ }^{1} \mathrm{H}$ and ${ }^{11} \mathrm{~B}\left\{{ }^{1} \mathrm{H}\right\}$ chemical shifts were given in Table S4.

The molecular orbital analyses show a relatively higher highest occupied molecular orbital (HOMO)-lowest unoccu- 


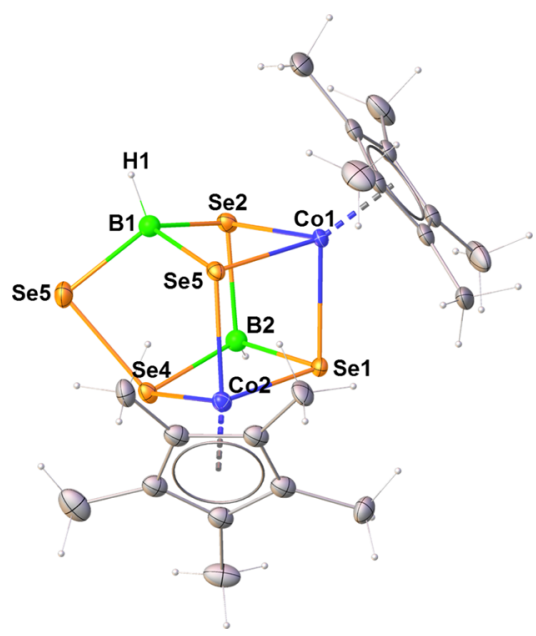

Figure 6. Molecular structures and labelling diagram of 7. Thermal ellipsoids are drawn at a $50 \%$ probability level. Selected bond lengths $[\AA]$ and angles $\left({ }^{\circ}\right)$ : Co1-Se1 2.3882(16), Co1-Se2 2.3947(18), Co1-Se3 2.3910(18), Co2-Se1 2.3909(19), Co2-Se3 2.3863(18), Co2-Se4 2.3437(19), B1-Se2 2.087(13), B1-Se3 2.075(13), B1Se5 2.035(12); Se1-Co1-Se3 84.78(6), Se3-Co2-Se1 84.82(6), Se5-B1-Se3 112.6(6), Se5-B1-Se2 108.8(6), Se3-B1-Se2 99.9(5), Se5-B1-H1 111.6, Se4-B2-Se2 105.1(6), Se4-B2-Se1 93.1(5), Se2-B2-Se1 96.7(5), Se2-B2-H2 119.0.

pied molecular orbital (LUMO) energy gap for $4(2.01 \mathrm{eV})$ compared to other homocubane analogues 1-3 and 5-7 (Table S2); the gap is minimum for $\mathbf{6}$ (Figure S33). The frontier molecular orbitals of all the molecules indicate that the HOMO is mostly localized at chalcogen E ( $\mathrm{S}$ or $\mathrm{Se}$ ) which suggests that the lone pairs of electrons are on E. On the other hand, the LUMO is located on Co which is antibonding interaction with $\mathrm{E}(\mathrm{E}=\mathrm{S}$ or Se) (Figures S33 and S34). The total percentage contribution of $\mathrm{Co}$, chalcogen $\mathrm{E}(\mathrm{E}=\mathrm{S}$ or $\mathrm{Se})$, and $\mathrm{B}$ to the HOMO and LUMO of all molecules are listed in Table S3. The HOMO of all molecules clearly suggests that their donation ability through the chalcogen $\mathrm{E}$ end, which may be useful to study the reactivity with small molecules such as silanes, boranes, and alkynes and so on. The natural charges obtained from natural bond orbital (NBO) analyses, shown in Table S2, reveal that all the cobalt and boron atoms show positive and negative charges, respectively (Table S3). The Wiberg bond index analyses suggest strong bonding interactions at $\mathrm{Co}-\mathrm{E}, \mathrm{B}-\mathrm{E}$, and $\mathrm{E}-\mathrm{E}$ bonds $(\mathrm{E}=\mathrm{S}$ or Se, Table $\mathrm{S} 1)$. The NBO calculations further support these bonding interactions, notably $\mathrm{Co}-\mathrm{H}-\mathrm{Co}$ bonding interaction (Figure S35). In addition, the analysis of the topology displays bond critical points (BCPs) between $\mathrm{Co}-\mathrm{E}$ and $\mathrm{B}-\mathrm{E}$ bonds, which suggests relatively similar charge distribution for $\mathbf{1}$ at $\mathrm{Co}_{2} \mathrm{E}$ and $\mathrm{E}_{2} \mathrm{~B}$ planes and for 5 and $\mathbf{6}$ at $\mathrm{CoE}_{2}$ and $\mathrm{B}_{2} \mathrm{E}$ planes (Figures 7, S36 and S37). The BCPs also signify higher electron density at $\mathrm{B}-\mathrm{E}$ relative to that of $\mathrm{Co}-\mathrm{E}$ bonds. Furthermore, electron localization function (ELF) values and negative energy density $(H(r))$ values indicate that the $\mathrm{B}-\mathrm{E}$ bonds are more covalent in nature as compared to the Co-E bonds (Table S5).

Electronic Spectra. The cubane cores of the homocubane clusters 1-7, consist of either one or two metal centers. Therefore, UV-vis spectra were recorded, for compounds 17 , in $\mathrm{CH}_{2} \mathrm{Cl}_{2}$ (Figure 8), so as to see the absorption pattern. The absorption pattern for these complexes seem to be like that seen in the case of homometallic cubane clusters $\left[(\mathrm{Cp} * \mathrm{Mo})_{4}\left(\mu_{4}-\mathrm{BH}\right)_{3} \mathrm{~B}_{4} \mathrm{H}_{4}\right]^{8 \mathrm{~b}}$ and $\left[(\mathrm{CpNi})_{4} \mathrm{~B}_{4} \mathrm{H}_{4}\right] .{ }^{23}$ The

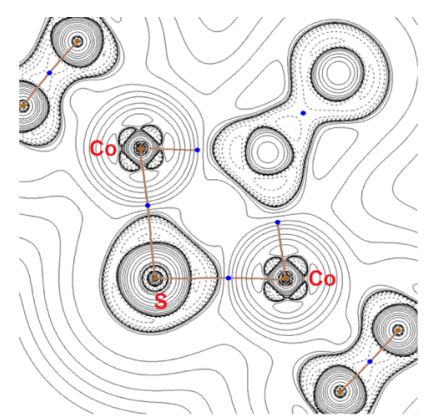

(a)

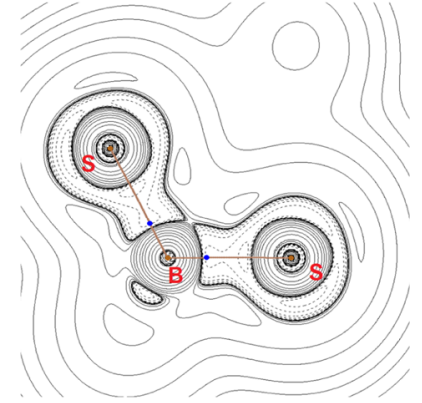

(b)
Figure 7. Contour line plots of the Laplacian of the electron density along (a) $\mathrm{Co}_{2} \mathrm{~S}$ and (b) $\mathrm{S}_{2} \mathrm{~B}$ planes for compound $\mathbf{1}$ obtained from the Multiwfn program package. Solid lines indicate the area of charge concentration $\left(\nabla^{2} \rho(r)<0\right)$ and dotted lines suggest the area of charge depletion $\left(\nabla^{2} \rho(r)>0\right)$. Blue dots indicate BCPs.

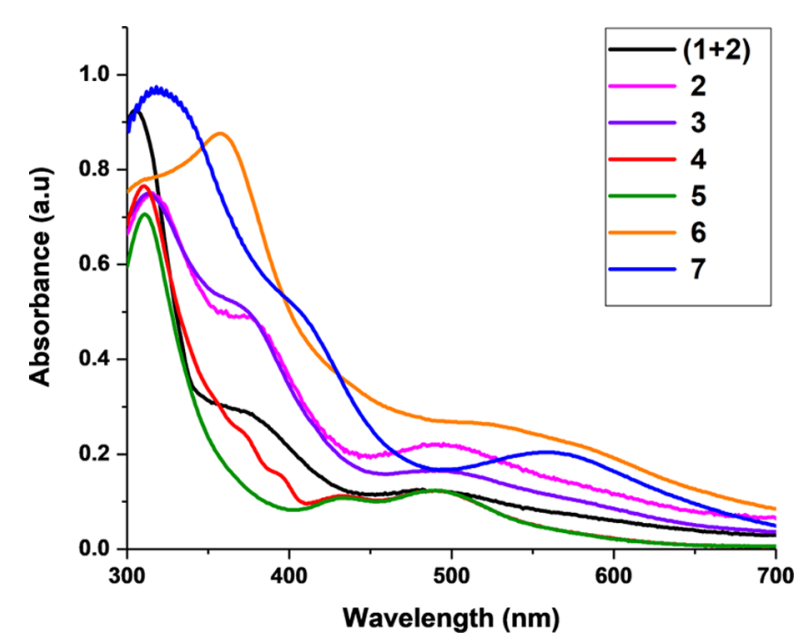

Figure 8. Absorption spectra of $1-7$ in $\mathrm{CH}_{2} \mathrm{Cl}_{2}\left(10^{-3} \mathrm{M}\right)$.

pattern also resembles that observed for the homometallic ruthenium cubanes, (i-iv) generated from nido$\left[(\mathrm{Cp} * \mathrm{RuH})_{2} \mathrm{~B}_{3} \mathrm{H}_{7}\right] .^{8 \mathrm{c}}$ All the compounds displayed a strong absorbance in the region 311-326 nm, which may be designated to $\pi-\pi^{*}$ transitions of the cyclopentadienyl ligands (Table 1). On the other hand, the bands in the region 375$563 \mathrm{~nm}$ may be because of charge transfer transition (MLCT). All the absorption bands manifest a red shift on moving from $\left[(\mathrm{CpNi})_{4} \mathrm{~B}_{4} \mathrm{H}_{4}\right]$ to $\mathbf{1 - 7}(\mathrm{ca} .30 \mathrm{~nm})$ (Table 1$)$. In spite of the presence of $\mathrm{Cp}^{*}$, the $\pi-\pi^{*}$ transition bands in compounds $1-$ 7 show a red shift unlike in compounds $\mathbf{i}-\mathbf{i v}$, where it shows a blue shift.

\section{CONCLUSIONS}

In summary, we have isolated and structurally characterized a series of unusual mono and dicobalta higher-order homocubane analogues, viz. tris and tetrahomocubane. All the structures possess essentially a cubane core, differing only in number and position of the $\mu_{2}-\mathrm{E}(\mathrm{E}=\mathrm{S}$ or $\mathrm{Se})$ bridges thereby generating a classified collection of derivatized homocubane analogues. The vertex-fused trishomocubane derivative, in which the $\left[\mathrm{Co}(\mu \text {-Se })_{3}\left(\mu_{3}-\mathrm{Se}\right)_{4} \mathrm{~B}_{3} \mathrm{H}_{3}\right]$ moiety is fused with an exopolyhedral trigonal bipyramid moiety, is quite exceptional. Synthesis of higher order homocubane or their derivatives is still a challenge and we believe that the approach we have 
Table 1. Absorption Spectra of 1-7 and Homometallic Cubane Clusters ${ }^{a}$

\begin{tabular}{lll}
\multicolumn{1}{c}{ compound } & \multicolumn{1}{c}{$\lambda_{\text {max }}, \mathrm{nm}$} & refs \\
{$\left[(\mathrm{CpNi})_{4} \mathrm{~B}_{4} \mathrm{H}_{4}\right]$} & $543,423,335,284$ & 23 \\
{$\left[(\mathrm{CpNi})_{4} \mathrm{~B}_{5} \mathrm{H}_{5}\right]$} & $548,365,302,257$ & 23 \\
{$\left[(\mathrm{Cp} * \mathrm{Mo})_{4}\left(\mu_{4}-\mathrm{BH}\right)_{3} \mathrm{~B}_{4} \mathrm{H}_{4}\right]$} & $440,364,315,239$ & $8 \mathrm{~b}$ \\
i & $513,368,248,206$ & $8 \mathrm{c}$ \\
ii & $499,370,253,209$ & $8 \mathrm{c}$ \\
iii & $429,318,204$ & $8 \mathrm{c}$ \\
iv & $481,372,258,209$ & $8 \mathrm{c}$ \\
$(\mathbf{1}+\mathbf{2})$ & $490,376,306$ & this work \\
$\mathbf{2}$ & $492,372,314$ & this work \\
$\mathbf{3}$ & $491,371,313$ & this work \\
$\mathbf{4}$ & $492,436,396,375,311$ & this work \\
$\mathbf{5}$ & $494,435,311$ & this work \\
$\mathbf{6}$ & $526,358,311$ & this work \\
$\mathbf{7}$ & $563,410,318$ & this work
\end{tabular}

$a_{\text {i, ii. }}\left[(\mathrm{Cp} * \mathrm{Ru})_{2}\left\{\mathrm{Ru}(\mathrm{CO})_{2}\right\} \mathrm{BH}(\mu-\mathrm{H}) \mathrm{B}(\mu-\mathrm{H})_{3} \mathrm{M}\left(\mu_{3}-\mathrm{E}\right)\right]$; i, $\mathrm{E}=\mathrm{CO}$, $\mathrm{M}=\mathrm{Cp} * \mathrm{Ru}$; ii, $\left.\mathrm{E}=\mathrm{BH}, \mathrm{M}=\mathrm{Ru}\left\{(\mathrm{Cp} * \mathrm{Ru})_{2}(\mu-\mathrm{H}) \mathrm{BH}(\mu \text {-CO })_{3}\right\}\right]$; iii. $\left[(\mathrm{Cp} * \mathrm{Ru})_{3}(\mathrm{BH})_{3}\left(\mu_{3}-\mathrm{H}\right)_{3}\left(\mu_{3}-\mathrm{CO}\right)\right] ;$ iv. $\left[(\mathrm{Cp} * \mathrm{Ru})_{2}\left(\mu_{3}-\mathrm{CO}\right)\{\mathrm{Ru}-\right.$ $\left.\left.(\mathrm{CO})_{3}\right\}_{2}(\mu-\mathrm{H}) \mathrm{B}(\mathrm{BH})_{2}\right]$.

utilized in this work might give an access to higher order homocubane analogues.

\section{EXPERIMENTAL SECTION}

General Procedures and Instrumentation. The operations were carried out under an Ar atmosphere by means of standard Schlenk line methods and glovebox. Solvents were distilled before use under an $\mathrm{Ar}$ atmosphere. $\left[\mathrm{LiBH}_{4} \cdot \mathrm{THF}\right], \mathrm{S}$, and Se powders were used as purchased from Sigma Aldrich. $[\mathrm{Cp} * \mathrm{CoCl}]_{2}{ }^{24}$ and $\left[\mathrm{BH}_{2} \mathrm{E}_{3}\right] \mathrm{Li}^{12}$ have been synthesized as per the literature methods. The reaction mixtures were separated by TLC which was done on silica gel TLC plates by Merck supported with $250 \mu \mathrm{m}$ diameter aluminum. $500 \mathrm{MHz}$ Bruker FT-NMR spectrometer, Agilent Technologies: 6545-Q-TOF LC/MS, JASCO FT/IR-4100 spectrometer, and Evolution 300 UV-vis spectrophotometer were used to record NMR, ESI mass, IR, and absorption spectra, respectively. Signals for residual protons in the deuterated solvents were used as reference in ${ }^{1} \mathrm{H}$ NMR $\left(\mathrm{CDCl}_{3}, \delta=7.26 \mathrm{ppm}, \mathrm{C}_{6} \mathrm{D}_{6}, \delta=7.16\right.$, toluene- $\left.d_{8}, \delta=7.09\right)$. For the ${ }^{11} \mathrm{~B}\left\{{ }^{1} \mathrm{H}\right\}$ NMR analysis, a sealed tube containing $\left[\mathrm{Bu}_{4} \mathrm{~N}\left(\mathrm{~B}_{3} \mathrm{H}_{8}\right)\right]^{25}$ in $\mathrm{C}_{6} \mathrm{D}_{6}\left(\delta_{\mathrm{B}}=-30.07 \mathrm{ppm}\right)$ was used as an external reference. Absorption spectra were recorded at $298 \mathrm{~K}$.

Synthesis of Compounds $1-3$ and 4. $\left[\mathrm{Cp}^{*} \mathrm{CoCl}\right]_{2}(0.1$ g, $0.218 \mathrm{mmol}$ ) was suspended in $10 \mathrm{~mL}$ toluene at room temperature, in a Schlenk tube which was flame-dried. To that, $\left[\mathrm{BH}_{2} \mathrm{~S}_{3}\right] \mathrm{Li}(2.18 \mathrm{mmol})$, was added as freshly prepared solution in toluene. The reaction then was allowed to stir for $16 \mathrm{~h}$ at room temperature. Drying of the solvent was done under vacuum followed by extraction of the residue in $n$ hexane/DCM $(50: 50 \mathrm{v} / \mathrm{v})$ by passing through Celite. The solvent was then removed and the resulting residue was then put through chromatographic work-up by means of TLC plates. Elution with $n$-hexane $/ \mathrm{CH}_{2} \mathrm{Cl}_{2}(50: 50 \mathrm{v} / \mathrm{v})$ yielded inseparable brown 1, 2, and $3\left(0.042 \mathrm{~g} ; R_{f}=0.5\right)$ and orange 4 $\left(0.030 \mathrm{~g}, 15 \% ; R_{f}=0.66\right)$. Further elution with toluene separated inseparable brown 1 and $2\left(0.020 \mathrm{~g} ; 14 \% ; R_{f}=0.66\right)$ (from the ${ }^{1} \mathrm{H}$ NMR we understood that the product ratio of 1 and 2 is 3:2, respectively) and brown 3 (0.020 g, 14\%; $R_{f}=$ $0.5)$.
1: $\mathrm{MS}\left(\mathrm{ESI}^{+}\right) \mathrm{m} / z$ : calculated for $\mathrm{C}_{20} \mathrm{H}_{32} \mathrm{~B}_{2} \mathrm{~S}_{8} \mathrm{Co}_{2}[\mathrm{M}]^{+}$, 667.9119; found, 667.9108. ${ }^{1} \mathrm{H}$ NMR (500 MHz, $\mathrm{C}_{6} \mathrm{D}_{6}, 22$ $\left.{ }^{\circ} \mathrm{C}\right): \delta=4.80\left(\mathrm{~s},{ }^{1} \mathrm{H}, \mathrm{B}-\mathrm{H}_{\mathrm{t}}\right), 4.22\left(\mathrm{~s},{ }^{1} \mathrm{H}, \mathrm{B}-\mathrm{H}_{\mathrm{t}}\right), 1.20 \mathrm{ppm}(\mathrm{s}$, $\left.30 \mathrm{H}, \mathrm{Cp}^{*}\right) ;{ }^{11} \mathrm{~B}\left\{{ }^{1} \mathrm{H}\right\}$ NMR (160 MHz, $\left.\mathrm{C}_{6} \mathrm{D}_{6}, 22{ }^{\circ} \mathrm{C}\right): \delta=$ -4.6, -13.9 ppm; ${ }^{13} \mathrm{C}\left\{{ }^{1} \mathrm{H}\right\}$ NMR (125 MHz, $\left.\mathrm{C}_{6} \mathrm{D}_{6}, 22^{\circ} \mathrm{C}\right): \delta$ $=95.3\left(\mathrm{C}_{5} \mathrm{Me}_{5}\right), 8.6 \mathrm{ppm}\left(\mathrm{C}_{5} \mathrm{Me}_{5}\right)$; IR (dichloromethane, $\left.\mathrm{cm}^{-1}\right): 2436\left(\mathrm{~B}-\mathrm{H}_{\mathrm{t}}\right)$.

2: $\mathrm{MS}\left(\mathrm{ESI}^{+}\right) \mathrm{m} / z$ : calculated for $\mathrm{C}_{20} \mathrm{H}_{33} \mathrm{~B}_{2} \mathrm{~S}_{7} \mathrm{Co}_{2}[\mathrm{M}+\mathrm{H}]^{+}$, 636.9477; found, 636.9450. ${ }^{1} \mathrm{H}$ NMR (500 MHz, $\mathrm{C}_{6} \mathrm{D}_{6}, 22$ $\left.{ }^{\circ} \mathrm{C}\right): \delta=5.26\left(\mathrm{~s}, 1 \mathrm{H}, \mathrm{B}-\mathrm{H}_{\mathrm{t}}\right), 4.23\left(\mathrm{~s}, 1 \mathrm{H}, \mathrm{B}-\mathrm{H}_{\mathrm{t}}\right), 1.32(\mathrm{~s}, 15 \mathrm{H}$, $\left.\mathrm{Cp}^{*}\right), 1.18 \mathrm{ppm}$ (s, 15H, Cp*); ${ }^{11} \mathrm{~B}\left\{{ }^{1} \mathrm{H}\right\}$ NMR (160 MHz, $\left.\mathrm{C}_{6} \mathrm{D}_{6}, 22{ }^{\circ} \mathrm{C}\right): \delta=5.2,3.6 \mathrm{ppm} ;{ }^{13} \mathrm{C}\left\{{ }^{1} \mathrm{H}\right\}$ NMR $(125 \mathrm{MHz}$, $\left.\mathrm{C}_{6} \mathrm{D}_{6}, 22{ }^{\circ} \mathrm{C}\right): \delta=96.0,94.6\left(\mathrm{C}_{5} \mathrm{Me}_{5}\right), 8.9,8.4 \mathrm{ppm}\left(\mathrm{C}_{5} \mathrm{Me}_{5}\right)$; IR (dichloromethane, $\left.\mathrm{cm}^{-1}\right)$ : 2519, $2363\left(\mathrm{~B}-\mathrm{H}_{\mathrm{t}}\right)$.

3: $\mathrm{MS}\left(\mathrm{ESI}^{+}\right) \mathrm{m} / z$ : calculated for $\mathrm{C}_{20} \mathrm{H}_{32} \mathrm{~B}_{2} \mathrm{~S}_{7} \mathrm{Co}_{2}[\mathrm{M}]^{+}$, 635.9399; found, 635.9366. ${ }^{1} \mathrm{H}$ NMR (500 MHz, $\mathrm{C}_{6} \mathrm{D}_{6}, 22$ $\left.{ }^{\circ} \mathrm{C}\right): \delta=4.47\left(\mathrm{~s}, 1 \mathrm{H}, \mathrm{B}-\mathrm{H}_{\mathrm{t}}\right), 4.22\left(\mathrm{~s}, 1 \mathrm{H}, \mathrm{B}-\mathrm{H}_{\mathrm{t}}\right), 1.36(\mathrm{~s}, 15 \mathrm{H}$, $\left.\mathrm{Cp}^{*}\right), 1.19 \mathrm{ppm}(\mathrm{s}, 15 \mathrm{H}, \mathrm{Cp} *) ;{ }^{11} \mathrm{~B}\left\{{ }^{1} \mathrm{H}\right\}$ NMR (160 MHz, $\left.\mathrm{C}_{6} \mathrm{D}_{6}, 22{ }^{\circ} \mathrm{C}\right): \delta=7.1,5.2 \mathrm{ppm} ;{ }^{13} \mathrm{C}\left\{{ }^{1} \mathrm{H}\right\}$ NMR $(125 \mathrm{MHz}$, $\left.\mathrm{C}_{6} \mathrm{D}_{6}, 22{ }^{\circ} \mathrm{C}\right): \delta=95.5,93.5\left(\mathrm{C}_{5} \mathrm{Me}_{5}\right)$, 9.5, $9.0 \mathrm{ppm}\left(\mathrm{C}_{5} \mathrm{Me}_{5}\right)$; IR (dichloromethane, $\left.\mathrm{cm}^{-1}\right)$ : 2436, $2373\left(\mathrm{~B}-\mathrm{H}_{\mathrm{t}}\right)$.

4: ${ }^{1} \mathrm{H}$ NMR $\left(500 \mathrm{MHz}, \mathrm{CDCl}_{3}, 22{ }^{\circ} \mathrm{C}\right): \delta=3.69$ (s, 3H, B$\left.\mathrm{H}_{\mathrm{t}}\right), 1.51 \mathrm{ppm}\left(\mathrm{s}, 15 \mathrm{H}, \mathrm{Cp}{ }^{*}\right) ;{ }^{11} \mathrm{~B}\left\{{ }^{1} \mathrm{H}\right\} \operatorname{NMR}(160 \mathrm{MHz}$, $\left.\mathrm{CDCl}_{3}, 22{ }^{\circ} \mathrm{C}\right): \delta=6.3 \mathrm{ppm} ;{ }^{13} \mathrm{C}\left\{{ }^{1} \mathrm{H}\right\}$ NMR $(125 \mathrm{MHz}$, $\left.\mathrm{CDCl}_{3}, 22{ }^{\circ} \mathrm{C}\right): \delta=95.5\left(\mathrm{C}_{5} \mathrm{Me}_{5}\right), 10.2 \mathrm{ppm}\left(\mathrm{C}_{5} \mathrm{Me}_{5}\right)$; IR (dichloromethane, $\left.\mathrm{cm}^{-1}\right): 2473\left(\mathrm{~B}-\mathrm{H}_{\mathrm{t}}\right)$.

Synthesis of Compounds 5, 6 and 7. The compounds 5, 6 , and 7 were synthesized from the reaction of $[\mathrm{Cp} * \mathrm{CoCl}]_{2}$ $(0.1 \mathrm{~g}, 0.2018 \mathrm{mmol})$ and $\left[\mathrm{BH}_{2} \mathrm{Se}_{3}\right] \mathrm{Li}(2.18 \mathrm{mmol})$ by employing the same reaction conditions as for compounds $1-$ 4. Orange 5 ( $\left.0.022 \mathrm{~g}, 6 \% ; R_{f}=0.64\right)$, brown 6 (0.012 g, 27\%; $\left.R_{f}=0.46\right)$, and grey $7\left(0.030 \mathrm{~g}, 17 \% ; R_{f}=0.56\right)$ were afforded on elution with $n$-hexane $/ \mathrm{CH}_{2} \mathrm{Cl}_{2}(60: 40 \mathrm{v} / \mathrm{v})$ in thin layer chromatographic work-up.

5: $\mathrm{MS}\left(\mathrm{ESI}^{+}\right) \mathrm{m} / z$ : calculated for $\mathrm{C}_{10} \mathrm{H}_{19} \mathrm{~B}_{3} \mathrm{Se} \mathrm{C}_{7} \mathrm{Co}[\mathrm{M}+\mathrm{H}]^{+}$, 783.3397; found, 783.6853. ${ }^{1} \mathrm{H}$ NMR $\left(500 \mathrm{MHz}, \mathrm{CDCl}_{3}, 22\right.$ $\left.{ }^{\circ} \mathrm{C}\right): \delta=5.05\left(\mathrm{~s}, 3 \mathrm{H}, \mathrm{B}-\mathrm{H}_{\mathrm{t}}\right), 1.57 \mathrm{ppm}(\mathrm{s}, 15 \mathrm{H}, \mathrm{Cp} *) ;{ }^{11} \mathrm{~B}\left\{{ }^{1} \mathrm{H}\right\}$ NMR $\left(160 \mathrm{MHz}, \mathrm{CDCl}_{3}, 22{ }^{\circ} \mathrm{C}\right): \delta=0.2 \mathrm{ppm} ;{ }^{13} \mathrm{C}\left\{{ }^{1} \mathrm{H}\right\} \mathrm{NMR}$ $\left(125 \mathrm{MHz}, \mathrm{CDCl}_{3}, 22{ }^{\circ} \mathrm{C}\right): \delta=114.9\left(\mathrm{C}_{5} \mathrm{Me}_{5}\right), 14.5 \mathrm{ppm}$ $\left(\mathrm{C}_{5} \mathrm{Me}_{5}\right)$; IR (dichloromethane, $\left.\mathrm{cm}^{-1}\right): 2462\left(\mathrm{~B}-\mathrm{H}_{\mathrm{t}}\right)$.

6: MS $\left(\mathrm{ESI}^{+}\right) \mathrm{m} / z$ : calculated for $\mathrm{C}_{20} \mathrm{H}_{34} \mathrm{~B}_{3} \mathrm{Se}_{9} \mathrm{Co}_{3}[\mathrm{M}]^{+}$, 1194.3519; found, $1194.3456 .{ }^{1} \mathrm{H}$ NMR (500 MHz, toluene$\left.d_{8}, 22{ }^{\circ} \mathrm{C}\right): \delta=1.33\left(\mathrm{~s}, 30 \mathrm{H}, \mathrm{Cp}^{*}\right),-3.60 \mathrm{ppm}(\mathrm{s}, 1 \mathrm{H}$; Co$\mathrm{H}-\mathrm{Co}) ;{ }^{11} \mathrm{~B}\left\{{ }^{1} \mathrm{H}\right\}$ NMR (160 MHz, toluene- $\left.d_{8}, 22^{\circ} \mathrm{C}\right): \delta=$ $-44.6 \mathrm{ppm} ;{ }^{13} \mathrm{C}\left\{{ }^{1} \mathrm{H}\right\}$ NMR (125 MHz, toluene- $\left.d_{8}, 22{ }^{\circ} \mathrm{C}\right): \delta=$ $112.4\left(\mathrm{C}_{5} \mathrm{Me}_{5}\right), 14.7 \mathrm{ppm}\left(\mathrm{C}_{5} M e_{5}\right)$; IR (dichloromethane, $\left.\mathrm{cm}^{-1}\right): 2437\left(\mathrm{~B}-\mathrm{H}_{\mathrm{t}}\right)$.

7: $\mathrm{MS}\left(\mathrm{ESI}^{+}\right) \mathrm{m} / z$ : calculated for $\mathrm{C}_{20} \mathrm{H}_{33} \mathrm{~B}_{2} \mathrm{Co}_{2} \mathrm{Se}_{5}[\mathrm{M}+$ $\mathrm{H}]^{+}$: 807.7223, found 807.7211. ${ }^{1} \mathrm{H} \mathrm{NMR}\left(500 \mathrm{MHz}, \mathrm{CDCl}_{3}\right.$, $\left.22{ }^{\circ} \mathrm{C}\right): \delta=4.42\left(\mathrm{~s}, 1 \mathrm{H}, \mathrm{B}-\mathrm{H}_{\mathrm{t}}\right), 1.64\left(\mathrm{~s}, 1 \mathrm{H}, \mathrm{B}-\mathrm{H}_{\mathrm{t}}\right), 1.58 \mathrm{ppm}$ $\left(\mathrm{s}, 30 \mathrm{H}, \mathrm{Cp}^{*}\right) ;{ }^{11} \mathrm{~B}\left\{{ }^{1} \mathrm{H}\right\}$ NMR $\left(160 \mathrm{MHz}, \mathrm{CDCl}_{3}, 22^{\circ} \mathrm{C}\right): \delta=$ -5.6, -12.9 ppm; ${ }^{13} \mathrm{C}\left\{{ }^{1} \mathrm{H}\right\} \mathrm{NMR}\left(125 \mathrm{MHz}, \mathrm{CDCl}_{3}, 22{ }^{\circ} \mathrm{C}\right)$ : $\delta=90.7,88.2 \mathrm{ppm}\left(\mathrm{C}_{5} \mathrm{Me}_{5}\right), 10.1,10.0 \mathrm{ppm}\left(\mathrm{C}_{5} \mathrm{Me}_{5}\right)$; IR (dichloromethane, $\left.\mathrm{cm}^{-1}\right): 2453,2368\left(\mathrm{~B}-\mathrm{H}_{\mathrm{t}}\right)$.

\section{ASSOCIATED CONTENT}

\section{Supporting Information}

The Supporting Information is available free of charge on the ACS Publications website at DOI: 10.1021/acsomega.9b02568.

$\mathrm{X}$-ray structure details, spectroscopic data for 1-7, computational details, optimized geometries, $\mathrm{MO}$ 
diagrams and contour line diagrams of the Laplacian of the electron density (PDF)

Crystallographic Information on Compound 1 (CIF) Crystallographic Information on Compound 3 (CIF) Crystallographic Information on Compound 4 (CIF) Crystallographic Information on Compound 6 (CIF) Crystallographic Information on Compound 7 (CIF)

\section{Accession Codes}

CCDC 1867997 (1), 1906648 (3) 1868165 (4) 1867999 (6) and 1867978 (7) contain the supplementary crystallographic data for this paper. These data can be obtained free of charge from the Cambridge Crystallographic Data Centre via www. ccdc.cam.ac.uk/data_request/cif.

\section{AUTHOR INFORMATION}

\section{Corresponding Author}

*E-mail: sghosh@iitm.ac.in. Phone: +91-44-22574230. Fax: +91 44-22574202.

\section{ORCID}

Sundargopal Ghosh: 0000-0001-6089-8244

\section{Author Contributions}

${ }^{\S}$ R.R. and M.Z. contributed equally to this work.

\section{Notes}

The authors declare no competing financial interest.

\section{ACKNOWLEDGMENTS}

We are grateful to CEFIPRA, grant number 5905-1, New Delhi, India, for supporting this work. We thank Dr. Babu Varghese and Dr. P. K. Sudhadevi Antharjanam for X-ray structure analyses. The computational facility of IIT Madras is gratefully acknowledged. K.P. and M.Z. thank IIT Madras and R.R. thanks University Grant Commission (UGC), India, for research fellowships.

\section{REFERENCES}

(1) (a) Marchand, A. P. Synthesis and chemistry of homocubanes, bishomocubanes, and trishomocubanes. Chem. Rev. 1989, 89, 10111033. (b) Paquette, L. A.; Stowell, J. C. Silver ion catalyzed rearrangements of strained sigma bonds. Application to the homocubyl and 1,1'-bishomocubyl systems. J. Am. Chem. Soc. 1970, 92, 2584-2586. (c) Dauben, W. G.; Whalen, D. L. Pentacyclo$\left[4 \cdot 4 \cdot 0 \cdot 0^{2,5} \cdot 0^{3,8} \cdot 0^{4,7}\right]$ decane and pentacyclo $\left[4 \cdot 3 \cdot 0 \cdot 0^{2,5} \cdot 0^{3,8} \cdot 0^{4,7}\right]$ nonane. Tetrahedron Lett. 1966, 3743-3750. (d) Masamune, S.; Cuts, H.; Hogben, M. G. Strained systems. VII. Pentacyclo[4.2.2.0 $\left.0^{2,5} \cdot 0^{3,8} .0^{4,7}\right]$ deca-9-ene, basketene. Tetrahedron Lett. 1966, 7, 1017-1021.

(2) (a) Eaton, P. E.; Cole, T. W. The cubane system. J. Am. Chem. Soc. 1964, 86, 962-964. (b) Eaton, P. E.; Cole, T. W. Cubane. J. Am. Chem. Soc. 1964, 86, 3157-3158. (c) Eaton, P. E. Cubanes: starting materials for the chemistry of the 1990s and the new century. Angew. Chem., Int. Ed. Engl. 1992, 31, 1421-1436. (d) Griffin, G. W.; Marchand, A. P. Synthesis and chemistry of cubanes. Chem. Rev. 1989, 89, 997-1010. (e) de Meijere, A.; Redlich, S.; Frank, D.; Magull, J.; Hofmeister, A.; Menzel, H.; König, B.; Svoboda, J. Octacyclopropylcubane and some of its isomers. Angew. Chem., Int. Ed. 2007, 46, 4574-4576.

(3) (a) Eaton, P. E.; Zhang, M. X.; Gilardi, R. L.; Gelber, N.; Iyer, S.; Rao, S. Octanitrocubane: a new nitrocarbon. Propellants, Explos., Pyrotech. 2002, 27, 1-6. (b) Eaton, P. E.; Gilardi, R. L.; Zhang, M. X. Polynitrocubanes: advanced high-density, high-energy materials. Adv. Mater. 2000, 12, 1143-1148.

(4) Mallick, L.; Thakker, H. K.; Sohan, L.; Kumar, S.; Namboothiri, I. N. N.; Chowdhury, A.; Kumbhakarna, N. Bishomocubanes as possible binders in composite solid propellants. 11th Asia-Pacific Conference on Combustion; University of Sydney, 2017.
(5) (a) Paquette, L. A.; Ward, J. S.; Boggs, R. A.; Farnham, W. B. Silver(I) ion catalyzed rearrangements at strained $\sigma$ bonds. XXVIII. Valence isomerization of homocubanes. Reversible complex formation and kinetic substituent effects operating during silver(I)-induced bond reorganization. J. Am. Chem. Soc. 1975, 97, 1101-1112. (b) Paquette, L. A.; Boggs, R. A.; Farnham, W. B.; Beckley, R. S. Silver(I) ion catalyzed rearrangements of strained $\sigma$ bonds. XXIX. Influence of structural features on the course of transition metal catalyzed 1,8-bishomocubane rearrangements. J. Am. Chem. Soc. 1975, 97, 1112-1118. (c) Paquette, L. A.; Boggs, R. A.; Ward, J. S. Silver(I) ion catalyzed rearrangements of strained $\sigma$ bonds. XXX. Rhodium(I)and Palladium(II)-promoted rearrangements of homocubanes. A comparison of kinetic reactivity and product distribution with substituent alteration. J. Am. Chem. Soc. 1975, 97, 1118-1124. (d) McNeal, C. J.; Liu, C. W.; Song, S.; Huang, Y.; Macfarlane, R. D.; Irwin, M. D.; Fackler, J. P., Jr. Characterization of $\left\{\mathrm{M}_{8}\left[\mathrm{~S}_{2} \mathrm{CC}\right.\right.$ $\left.\left.(\mathrm{CN})_{2}\right]_{6}\right\}^{4-}$, where $\mathrm{M}=\mathrm{Cu}^{\mathrm{I}}$ and $\mathrm{Ag}^{\mathrm{I}}$, homocubane clusters by ${ }^{252} \mathrm{Cf}-$ plasma desorption mass spectrometry. Int. J. Mass Spectrom. 2003, 222, 493-501.

(6) Adams, R. D.; Miao, S. Cyclopentadienylcobalt sulfide and selenide cluster compounds: synthesis and structural characterizations. Inorg. Chim. Acta 2005, 358, 1401-1406.

(7) Ogino, H.; Inomata, S.; Tobita, H. Abiological Iron-Sulfur clusters. Chem. Rev. 1998, 98, 2093-2121.

(8) (a) Geetharani, K.; Bose, S. K.; Sahoo, S.; Ghosh, S. A family of heterometallic cubane-type clusters with an exo- $\mathrm{Fe}(\mathrm{CO})_{3}$ fragment anchored to the cubane. Angew. Chem., Int. Ed. 2011, 50, 3908-3911. (b) Thakur, A.; Sao, S.; Ramkumar, V.; Ghosh, S. Novel class of heterometallic cubane and boride clusters containing heavier group 16 elements. Inorg. Chem. 2012, 51, 8322-8330. (c) Yuvaraj, K.; Roy, D. K.; Mondal, B.; Varghese, B.; Ghosh, S. Homometallic Cubane Clusters: Participation of Three-Coordinated Hydrogen in 60-Valence Electron Cubane Core. Inorg. Chem. 2015, 54, 8673-8678.

(9) (a) Roy, D. K.; Mondal, B.; Shankhari, P.; Anju, R. S.; Geetharani, K.; Mobin, S. M.; Ghosh, S. Supraicosahedral polyhedra in metallaboranes: synthesis and structural characterization of 12-, 15-, and 16-vertex rhodaboranes. Inorg. Chem. 2013, 52, 6705-6712. (b) Kar, S.; Saha, K.; Saha, S.; Bakthavachalam, K.; Ghosh, S. Trimetallic cubane-type clusters: transition-metal variation as a probe of the roots of hypoelectronic metallaheteroboranes. Inorg. Chem. 2018, 57, 10896-10905.

(10) (a) Borthakur, R.; Mondal, B.; Nandi, P.; Ghosh, S. Hypoelectronic isomeric diiridaboranes $\left[(\mathrm{Cp} * \mathrm{Ir})_{2} \mathrm{~B}_{6} \mathrm{H}_{6}\right]$ : the "RuleBreakers" $\left(\mathrm{Cp}^{*}=\eta^{5}-\mathrm{C}_{5} \mathrm{Me}_{5}\right)$. Chem. Commun. 2016, 52, 3199-3202. (b) De, A.; Zhang, Q.-F.; Mondal, B.; Cheung, L. F.; Kar, S.; Saha, K.; Varghese, B.; Wang, L.-S.; Ghosh, S. $\left[\left(\mathrm{Cp}_{2} \mathrm{M}\right)_{2} \mathrm{~B}_{9} \mathrm{H}_{11}\right](\mathrm{M}=\mathrm{Zr}$ or $\mathrm{Hf}$ ): early transition metal "guarded" heptaborane with strong covalent and electrostatic bonding. Chem. Sci. 2018, 9, 1976-1981. (c) Mondal, B.; Bag, R.; Ghorai, S.; Bakthavachalam, K.; Jemmis, E. D.; Ghosh, S. Synthesis, structure, bonding and reactivity of metal complexes comprising diborane(4) and diborene $(2)$ : $[\{\mathrm{Cp} * \mathrm{Mo}-$ $\left.\left.(\mathrm{CO})_{2}\right\}_{2}\left\{\mu-\eta^{2}: \eta^{2}-\mathrm{B}_{2} \mathrm{H}_{4}\right\}\right]$ and $\left[\left\{\mathrm{Cp} * \mathrm{M}(\mathrm{CO})_{2}\right\}_{2} \mathrm{~B}_{2} \mathrm{H}_{2} \mathrm{M}(\mathrm{CO})_{4}\right]$, $\mathrm{M}=\mathrm{Mo}$, W. Angew. Chem., Int. Ed. 2018, 57, 8079-8083.

(11) (a) Anju, R. S.; Saha, K.; Mondal, B.; Dorcet, V.; Roisnel, T.; Halet, J.-F.; Ghosh, S. Chemistry of diruthenium analogue of pentaborane(9) with heterocumulenes: toward novel trimetallic cubane-type clusters. Inorg. Chem. 2014, 53, 10527-10535. (b) Barik, S. K.; Rao, C. E.; Yuvaraj, K.; Jagan, R.; Kahlal, S.; Halet, J.-F.; Ghosh, S. Electron-precise 1,3-bishomocubanes: a combined experimental and theoretical study. Eur. J. Inorg. Chem. 2015, 33, $5556-5562$

(12) (a) Lalancette, J. M.; Freche, A.; Monteux, R. Reductions with sulfurated borohydrides. I. Preparation of sulfurated borohydrides. Can. J. Chem. 1968, 46, 2754-2757. (b) Lalancette, J. M.; Arnac, M. Reductions with sulfurated borohydrides. III. Borohydrides incorporating selenium and tellurium. Can. J. Chem. 1969, 47, 3695-3697. (c) Ramalakshmi, R.; Saha, K.; Paul, A.; Ghosh, S. Reactivity of $\left[\mathrm{Cp} * \mathrm{Mo}(\mathrm{CO})_{3} \mathrm{Me}\right]$ with chalcogenated borohydrides $\mathrm{Li}\left[\mathrm{BH}_{2} \mathrm{E}_{3}\right]$ and 
$\mathrm{Li}\left[\mathrm{BH}_{3} \mathrm{EFc}\right]\left(\mathrm{Cp}^{*}=\left(\eta^{5}-\mathrm{C}_{5} \mathrm{Me}_{5}\right) ; \mathrm{E}=\mathrm{S}\right.$, Se or Te; Fc $=\left(\mathrm{C}_{5} \mathrm{H}_{5}-\mathrm{Fe}-\right.$ $\left.\left.\mathrm{C}_{5} \mathrm{H}_{4}\right)\right)$. J. Chem. Sci. 2016, 128, 1025-1032.

(13) (a) Note that compound 2 was isolated in pure from compound 3 that allowed us to assign the spectroscopic data of both $\mathbf{1}$ and $\mathbf{2}$ without any ambiguity. Moreover, although the spectral data of 1 could be comprehended from the molecular structure of 1 , the ${ }^{11} \mathrm{~B}\left\{{ }^{1} \mathrm{H}\right\}$ and ${ }^{1} \mathrm{H}$ chemical shift values could not be unambiguously assigned until the pure spectroscopic data for 2 was realized.

(14) (a) Bose, S. K.; Geetharani, K.; Ramkumar, V.; Varghese, B.; Ghosh, S. Chemistry of vanadaboranes: synthesis, structures, and characterization of organovanadium sulfide clusters with disulfido linkage. Inorg. Chem. 2010, 49, 2881-2888. (b) Dhayal, R. S.; Chakrahari, K. K. V.; Varghese, B.; Mobin, S. M.; Ghosh, S. Chemistry of molybdaboranes: synthesis, structures, and characterization of a new class of open-cage dimolybdaheteroborane clusters. Inorg. Chem. 2010, 49, 7741-7747.

(15) (a) Ahlgren, G.; Åkermark, B.; Karlsson, R.; Pilotti, Å.; Lindberg, A. A.; Ehrenberg, L. Photodimerization of 1,4-Cyclohexadiene-1,2-dicarboxylic Anhydride to Pentacyclo[6.4.0.0(2,7).0$(4,11) \cdot 0(5,10)]$-dodecane-1,2,5,10-tetracarboxylic Dianhydride. Acta Chem. Scand. 1971, 25, 753. (b) Fritz, H.-G.; Hutmacher, H.-M.; Musso, H.; Ahlgren, G.; Åkermark, B.; Karlsson, R. Asterane, XIII Synthese des Tetraasterans durch Photodimerisierung von 3,6Dihydrophthalsäure-anhydrid. Chem. Ber. 1976, 109, 3781-3792.

(16) Stark, J. L.; Harms, B.; Guzman-Jimenez, I.; Whitmire, K. H.; Gautier, R.; Halet, J.-F.; Saillard, J.-Y. Different ways to distort a tetracapped tetrahedron on route to forming an $\mathrm{E}_{4} \mathrm{M}_{4}$ Cubane: the case of $\left[\mathrm{E}_{4}\left(\mathrm{Pd}\left(\mathrm{PPh}_{2} \mathrm{Me}\right)_{2}\right)_{4}\right]\left[\mathrm{Ph}_{2} \mathrm{EX}_{2}\right]_{2}(\mathrm{E}=\mathrm{Sb}, \mathrm{X}=\mathrm{Cl} ; \mathrm{E}=\mathrm{Bi}, \mathrm{X}=$ Br). J. Am. Chem. Soc. 1999, 121, 4409-4418.

(17) The cve of bishomocubane derivative, $\left[(\mathrm{Cp} * \mathrm{Rh})_{2}(\mu-\mathrm{E})_{2}\left(\mu_{3}\right.\right.$ E) $\left.{ }_{4} \mathrm{~B}_{2} \mathrm{H}_{2}\right]$ is $72[14(\mathrm{Cp} * \mathrm{Rh}) \times 2+6(\mathrm{~S}, \mathrm{Se}) \times 6+4(\mathrm{BH}) \times 2]$ and for ruthenium analogue $\left[(\mathrm{Cp} * \mathrm{Ru})_{2}(\mu-\mathrm{E})_{2}\left(\mu_{3}-\mathrm{E}\right)_{4} \mathrm{~B}_{2} \mathrm{H}_{2}\right](\mathrm{E}=\mathrm{S}$ or $\mathrm{Se})$ it is 70 . Note that the shortage of two electrons for the latter is supplemented by the formation of one $\mathrm{Ru}-\mathrm{Ru}$ bond.

(18) Cameron, T. S.; Jochem, K.; Linden, A.; Morris, D. G.; Shepherd, A. G. Pitfalls of a disordered structure: distinguishing the compound present, 4-iodomethyl-1,7,7-trimethyl-3-oxabicyclo[2.2.1]heptan-2-one, from 5-iodomethyl-1,2,2-trimethyl-4-oxabicyclo[3.2.0]heptan-3-one. Acta Crystallogr. 1989, 45, 167-171.

(19) (a) Underwood, G. R.; Ramamoorthy, B. Chemical studies of caged compounds. II the synthesis of pentacyclo $\left[6,3,0,0^{2,6}, 0^{3,10}, 0^{5,9}\right]$ undecane: trishomocubane. Tetrahedron Lett. 1970, 11, 4125-4127. (b) Godleski, S. A.; Schleyer, P. v. R. Syntheses of $\left(D_{3}\right)$ trishomocubane (pentacyclo $\left[6,3,0,0^{2,6}, 0^{3,10}, 0^{5,9}\right]$ undecane) by rearrangement. J. Chem. Soc., Chem. Commun. 1974, 976b-977. (c) Kent, G. J.; Godleski, S. A.; Osawa, E.; Schleyer, P. v. R. Syntheses and relative stability of $\left(D_{3}\right)$-trishomocubane (pentacyclo$\left[6.3 \cdot 0.0^{2,6} \cdot 0^{3,10} \cdot 0^{5,9}\right]$ undecane), the pentacycloundecane stabilomer. $J$. Org. Chem. 1977, 42, 3852-3859. (d) Helmchen, G.; Staiger, G. Synthesis and Absolute Configuration of Enantiomerically Pure $D_{3}$ Trishomocubanes(pentacyclo[6.3.0.0 $\left.0^{2,6} \cdot 0^{3,10} \cdot 0^{5,9}\right]$ undecane) and Trishomocubanones. Angew. Chem., Int. Ed. Engl. 1977, 16, 116-117. (20) Krishnamoorthy, B. S.; Thakur, A.; Chakrahari, K. K. V.; Bose, S. K.; Hamon, P.; Roisnel, T.; Kahlal, S.; Ghosh, S.; Halet, J.-F. Theoretical and experimental investigations on hypoelectronic heterodimetallaboranes of group 6 transition metals. Inorg. Chem. 2012, 51, 10375-10383.

(21) Schneider, J. J.; Specht, U.; Goddard, R.; Kriigerl, C. Metal Atoms in the Synthesis of Metal Clusters, VIII. On the Reaction of Sterically Demanding Cyclopentadiene Ligands with Cobalt Atoms: Synthesis, Crystal Structure, Spectroscopic Behavior, and Reactivity of Di-, Tri- and Tetranuclear Hydrido Clusters of Cobalt. Chem. Ber./ Recl. 1997, 130, 161-170.

(22) (a) Wade, K. The structural significance of the number of skeletal bonding electron-pairs in carboranes, the higher boranes and borane anions, and various transition-metal carbonyl cluster compounds. J. Chem. Soc. D 1971, 0, 792-793. (b) Wade, K. Structural and bonding patterns in cluster chemistry. Adv. Inorg. Chem. Radiochem. 1976, 18, 1-66. (c) Fox, M. A.; Wade, K. Evolving patterns in boron cluster chemistry. Pure Appl. Chem. 2003, 75, 1315-1323. (d) Mingos, D. M. P. Polyhedral skeletal electron pair approach. Acc. Chem. Res. 1984, 17, 311-319. (e) Jemmis, E. D.; Balakrishnarajan, M. M.; Pancharatna, P. D. A unifying electroncounting rule for macropolyhedral boranes, metallaboranes, and metallocenes. J. Am. Chem. Soc. 2001, 123, 4313-4323. (f) Jemmis, E. D.; Balakrishnarajan, M. M.; Pancharatna, P. D. Electronic Requirements for Macropolyhedral Boranes. Chem. Rev. 2002, 102, 93-144.

(23) Pipal, J. R.; Grimes, R. N. Crystal structure of a tetracobalt tetraboron cluster, $\left(\eta^{5}-\mathrm{C}_{5} \mathrm{H}_{5}\right)_{4} \mathrm{Co}_{4} \mathrm{~B}_{4} \mathrm{H}_{4}$. Structural patterns in eightvertex polyhedra. Inorg. Chem. 1979, 18, 257-263.

(24) Yoshino, T.; Ikemoto, H.; Matsunaga, S.; Kanai, M. A Cationic High-Valent Cp*CoIII Complex for the Catalytic Generation of Nucleophilic Organometallic Species: Directed $\mathrm{C}-\mathrm{H}$ Bond Activation. Angew. Chem., Int. Ed. 2013, 52, 2207-2211.

(25) Ryschkewitsch, G. E.; Nainan, K. C. Octahydrotriborate(1-) $\left(\left[\mathrm{B}_{3} \mathrm{H}_{8}\right]^{-}\right)$salts. Method A. Inorg. Synth. 1974, 15, 113-114. 